\author{
Varvara A. Byachkova \\ Perm State University, Russia \\ bvarvara@yandex.ru
}

\title{
Unhappy Birthdays in the Novels by F.H. Burnett (A Little Princess) and Charles Dickens (David Copperfield)
}

This article deals with "unhappy birthdays" in the novels of Charles Dickens and Frances Hodgson Burnett. Both writers follow the folklore tradition of depicting young characters who have to take care of themselves after a parent's death. In the novels David Copperfield and A Little Princess, the news of their parent's death comes on the child's birthday. This article studies why this particular day is chosen, under what circumstances the children survive their trauma and what makes them capable of moving on. The news of the parent's death on the child's birthday seems to mark the start of a new period in each character's life, a test that has to be passed. Having passed the test and won a moral victory over the circumstances, the child gets an opportunity to move on and be happy again.

Keywords: birthday, F.H. Burnett, children, Charles Dickens, Victorian novel, Edwardian novel

The author of this article has already tried to answer the question of what can be called "the boundary of childhood" in the Victorian and Edwardian novel (see Byachkova 2015). The most natural event which marks the end of childhood is the death of a parent (or both parents or even guardians if a young character is already an orphan at the beginning of the novel). Parents and guardians do die in novels by Charles Dickens, Elizabeth Gaskell, Charlotte Brontë and other Victorian novelists. M.A. Kimball wrote about the special place and role of an orphan child in society, which is also reflected in Victorian literature. Orphans, among other things, "symbolize our isolation from one another and from society", having stopped being part of a family structure (Kimball 1999: 559). But often it seems that what is important is not death itself and the isolation of the orphan, but the fact that an orphan child has to take care of himself or herself. Orphans make choices, take decisions, act on their own, and assume responsibility for their own future just like an adult. 
In fact, this crucial moment sometimes happens on the child's birthday. Such a plot pattern can be found in the novels by F.H. Burnett (A Little Princess, 1905) and, earlier, by Charles Dickens (David Copperfield, 1850). The parents in both novels do not actually die on the children's birthday, but David and Sara are away from their mother and father. For them, their parents are still alive until they get news of their death. And the news comes precisely on the characters' birthday, connecting forever a day of feast and pleasure with the terrible blow. This article analyses this plot pattern, which has not previously received much study, and even less study when the works of Dickens and F.H. Burnett are put in comparison.

It is known that the novel $A$ Little Princess was influenced by the unfinished book Emma by Charlotte Brontë (see Cory 2013) rather than by Dickens. F.H. Burnett, inspired by the image of a child left all alone by her friends in a boarding school as portrayed in the unfinished novel of Charlotte Brontë, wrote her own version of the story with her own explanation as to why the child was abandoned and how she managed to survive the ordeal. But we should not forget that the general influence of Dickens on later generations of English and American writers is indisputable and that F.H. Burnett could not have avoided it. Burnett and Dickens both create the child's image following the concept of the Romantic child, developed from Jean-Jacques Rousseau and the poems of William Blake. The Romantic child is not only innocent, but wise and also beautiful (though later the child's beauty becomes irrelevant) (see Coveney 1967: 37, or Andrews 2000: 91). According to Peter Coveney, "Dickens is a central figure in the transference of the Romantic child into the Victorian novel" (1967: 110), although Dickens' David Copperfield is not only innocent, but also "observing" and "sharp" (see Dickens 2000, Chapter 2). Burnett also creates her images of children close to the concept of the Romantic child. Her main character in Little Lord Fauntleroy was the almost perfect Romantic child: not only innocent and wise, but beautiful (Carpenter 1985: 107-108). However, just like Dickens, Burnett, especially in her later works, became more interested in the child's mind. The main character of $A$ Little Princess, Sara Crewe, is clever, well behaved, noble, lovable and, in many respects, exemplary for young readers. The concept of the Romantic child makes it possible to compare David Copperfield and A Little Princess, as do several similar images, ideas, storylines and plot patterns that these two novels share. The plot pattern of the "unhappy birthday", when the main character is told about the death of his mother (David) or her father (Sara) is one of them. We shall see what the roots of such a plot pattern are, how the two authors organise their characters' "initiation ceremony" (the changes in time, space, etc.) and what helps the children pass all the tests and become happy again and thrive.

It might be supposed that, using the image of the Romantic child, the authors would follow other trends of Romanticism, for example, the folklore and fairy-tale traditions. Fairy tales about children, as mentioned for example by Vladimir Propp, more often than not are stories about growing up, initiation, maturity, so it is only logical that they start with children being left alone without their parents' guidance (nobody to guide them, give advice, etc.) (see Propp 2000: 22). Although the works of 
Burnett and Dickens are much more complex than folklore tales, both authors still use the very same plot pattern.

The choice of a child's birthday as the starting point of independent life, on the one hand, is connected with a very long folklore tradition of initiation ceremonies, which even today are still performed in certain cultures or religions (such as Bar Mitzvah for example). As we know, such ceremonies were (and are) performed either on the child's known birthday or close to it. We will note here that the loss of a parent in the novel may have become a new variant of the initiation ceremony. In English literary tradition, we can trace it as far back as William Shakespeare. Shakespeare's twins in Twelfth Night had lost their father on their birthday: "My father had a mole upon his brow / [...] And died that day when Viola from her birth / Had numbered thirteen years" (Shakespeare 2005: 741).

On the other hand, it goes without saying that in the times of Charles Dickens and F.H. Burnett, as in other periods, the death of a parent on a child's birthday was considered a double tragedy. It is terrible to lose one's parent on any day, but when the grief and loss come suddenly on the day which is supposed to be a merry holiday, the sorrow becomes almost unbearable. So, for Sara and David the unhappy birthday is not only the ceremony of initiation and the end of childhood, but also a recurrent trauma, because there is the chance that these children might have uncontrollable painful memories about the "unhappy" holiday every time they have a birthday. The end of childhood sadly changes the children's lives dramatically, since both must work after their parents' death. But with the problem of earning money (or, in Sara's case, the right to be fed and kept at school) comes the problem of being fully responsible for oneself not only financially, but morally and psychologically.

David's problems start long before the unhappy birthday. By the time of his mother's death, David is already severely traumatised by his cruel stepfather. The boy's happy babyhood with his loving mother and faithful nurse remains only in his memory. In fact, David has no home, since he is sent to Mr. Creakle's school to be got rid of as well as to be humiliated rather than educated. The news of his mother's death comes as one more blow in a line of losses and ordeals, but this does not lessen the child's sudden sorrow. David was not quite so enthusiastic about his birthday, but, summoned by Mr. Creakle, he still expected some presents, some fun (as a child should on his or her birthday) more likely in the form of "a hamper from Peggotty". Instead, he learns that now he is "an orphan in the wide world" and a "desolate cry" is all he can mutter (Dickens 2000: 108-109).

The boy's life changes immediately; David leaves Salem House. This is not the only change. The ceremony of initiation of ancient times more often than not included a formal change of clothes (as a symbol of changing identity) and a moment of solitude and silence (so the initiation could be properly meditated on). David goes through both stages of his initiation process. First, there is a scene in the shop of an undertaker, Mr. Omer. As we know, the culture of mourning clothes in Victorian and Edwardian times was very important (see Flanders 2004: 340-348). Researchers like John Carey 
also mention that the themes of death, coffins and mourning particularly interested Dickens and "stimulated his imagination" (1991: 80). In Mr. Omer's shop, this strange place with both a philosophical and practical attitude to death, Dickens emphasises the character's feelings at the point of changing clothes. When David is taken to Mr. Omer's shop to get his mourning clothes, he, not having lost his talent of observing (this part of his personality remains untouched by the trauma), makes the discovery that the world untouched by his grief still exists, that other people can still be happy: "I do not think I experienced so strange a feeling in my life [...]. I was not angry with them; I was more afraid of them [...]. They were very cheerful" (Dickens 2000: 113). He understands that he is shut off from the world around him. Later on, David's isolation becomes almost absolute. He takes time off from the world in his room, barely talking to anybody, especially when his loyal friend Peggotty is dismissed. Mr. Murdstone who, not long before, had insisted on David's presence in the sitting room every day, after burying his wife and baby son, seems to forget about his stepchild entirely. Until he is sent to work in London, David marvels at Murdstone's forgetfulness about him (see the chapter "I Become Neglected...," (Dickens 2000: 117-134). The unhappy birthday seems to stop time, nothing changes ("Day after day, week after week, month after month, I was coldly neglected" (131)). For David, the notion of time is connected with education, studies, intellectual growth. Later on, he is worried that his education is over forever and he is going to decline. David feels ashamed of his rough work at Murdstone and Grinby's, and "felt my hopes of growing up to be a learned and distinguished man crushed in my bosom" (Dickens 2000: 136). K.J. Fielding was perfectly right to describe David's state as "agony" due to "loneliness and desperation" (1960: 141). The child is very close to spiritual and emotional death. But such a state sometimes symbolises the beginning of a new life. The boy is born anew when he himself finds the solution. Having understood that he is now totally responsible for his life and his future, David comes to a "resolution" to find his distant aunt Betsey Trotwood who is to become his true guardian.

An interesting detail is that David is a posthumous child, his father (the parent of the same sex as the child) died before the boy was born. From babyhood, David "replaces" his father as "the man of the house", a partner for his widowed mother, part of a couple that resembles a married one (unity between man and woman). His mother's remarriage and death breaks this harmony, but later it is partly restored. David chooses his aunt for his guardian. He becomes a useful addition to her household. Betsey Trotwood is separated from her husband and lives with her maid and childish Mister Dick (another Romantic child who, unlike David, does not grow up). This is, mostly, a female world. David, young as he is, becomes "the man of the house" once again, a male companion to his aunt, especially when he grows older or when Betsey loses her money. At her house, David gets the chance to start a new life, to take up his education and be happy again.

In A Little Princess, Sara is sent to school because she needs to leave India for health reasons. Unlike David, she is still very much loved by her father. She also substitutes for her missing mother by being her father's companion. Her mother died when Sara was 
born, so she also replaces her by her father's side. Perhaps that is why the parents in both novels are described as young and good looking: "Bewitching Mrs. Copperfield" (Dickens 2000: 24), "her young, handsome father" (Burnett 1995: 8). But in Sara's case, the separation of father and daughter is more painful because there was no stepparent as in David's case, and the bond between father and daughter is stronger than the one between David and his mother.

The girl is also happier at school than David is. She misses her father but gains some education at Miss Minchin's (she is really fond of reading and learning), finds true friends and although not really much liked by the schoolmistress and some schoolmates, she is treated well (because she is rich). Learning the news of her father's death, Sara, like David, is, however, not deprived of happiness on her birthday forever. David's mother and Sara's father do not actually die on the children's birthdays; the children only learn about their losses on this day. Since the day is not connected with the parent's death, but with the news of it, the grief which ends the characters' childhood is later alleviated. The children are left with an opportunity to recover from their grief, to live, prosper and celebrate their birthdays happily when the first ordeals of orphan life are over. But the shock of a father's death is great: the girl had only just received her birthday presents. Some of them are from her father, and having just enjoyed these signs of his love, Sara learns that she is all alone. The terrible news changes Sara's life dramatically because she is believed to be penniless after her father's death and is transformed into half-teacher, half-maid at Miss Minchin's school.

The ritual of a change of clothing in Burnett's novel becomes Sara's first humiliation. She is ordered to wear an "old black velvet frock she has outgrown" (Burnett 1995: 86). Miss Minchin is so greedy and cruel that the child is not even allowed a new dress to mourn her father properly. Fighting this cruelty makes Sara a heroine. The image of a child in an old dress (which very soon becomes rags) is, as in the literature of the $19^{\text {th }}$ century, "linked to the concept of sentimentality" (Wynne 2015: 40). Sentimentality here is a synonym of sympathy, and the rags add to the heroine's distress and to the pity and support Sara gains from the readers. Poverty isolates Sara from the world. Nobody disturbs her in the attic, and the girl has enough time to grieve. The difference here is that Sara, in the first days of her sorrow, does not have friends who can really comfort her. David can fall into the arms of his kind nurse Peggotty, to cry, and listen to the story of his mother's last hours, but there are no adults to comfort Sara. The love of her little pupils, the sympathy of her friends, and the loyalty of Becky, the scullery maid (who still calls Sara "Miss" despite everything, and supports her) are not enough. Thinking of all that, Sara for once bursts out yelling at her doll Emily: "I can't bear this," [...]. "You are nothing but a doll!" [...] "[...] You care for nothing. [...] You never had a heart. [...]" (Burnett 1995: 132-133).

Sara's battle with the cruel world is even more psychologically difficult than David's. She sees that Miss Minchin is not only cruel, but illogical. The headmistress summons the girl and requires the absence of "crying or unpleasant scenes" but when Sara enters as calm, reserved, and polite as usual, Miss Minchin is irritated: "Don't put on grand 
airs," she said. "The time for that sort of thing is past" (Burnett 1995: 90-93). The girl also discovers that she cannot soften the hearts around her, however much she tries (99). Obedience and politeness may still be crucial virtues (exactly as they were in the times of Dickens and in his novels, too (see Grylls 1978: 150), but in Sara's case they do not help. Instead, the girl works hard to continue her studies whatever the difficulties, and keeps repeating to herself: "If I do not remind myself of the things I have learned, perhaps I may forget them," she said to herself. "I am almost a scullery-maid, and if I am a scullery maid who knows nothing I shall be like poor Becky. [...]" (Burnett 1995: 100).

In Sara's case, time plays even more amazing tricks than in Dickens' novel. It seems that time has completely stopped at Miss Minchin's after Sara's $11^{\text {th }}$ birthday. Sara is seven when she is introduced to Miss Minchin (Burnett 1995: 7). The age of the other pupils at school varies "from Lavinia Herbert, who was nearly thirteen and felt quite grown up, to Lottie Legh, who was only just four and the baby of the school" (20). Sara's unhappy birthday is her eleventh (69). She spends two years in the attic and leaves Miss Minchin's Academy aged 13 (234). In total, this adds up to five years. The curious point is that in those five years that Sara stays at Miss Minchin's, neither Lavinia, the eldest pupil, not Lottie, the youngest, changes much. Lottie, for example, is supposed to be seven on the day of Sara's unhappy birthday and nine by the end of the novel, but she seems to be still "the baby of the school". For example, she seems to be unable to comprehend what happens to Sara ("She $[\ldots]$ was much bewildered by the alternations she saw in her young adopted mother", 110) and asks questions that may be considered childish for a seven-year-old girl: "Are you very poor now Sara? Are you as poor as a beggar? [...] Where do you live? Is it a nice one [room]?" (ibid.). Close to the end of the novel, when it is revealed that Miss Minchin knew about Sara's and Ermengarde's secret meetings in the attic, Lavinia says about nine-year-old Lottie (two years older than Sara was when she came from India): "She's such a baby, she didn't know she was telling me" (Burnett 1995: 209).

As for Lavinia, she is nearly eighteen when Sara is removed from school. First of all, the question naturally arises: is it not time for her to return home, to go out, get a husband? What is more, she does not behave like a grown up at all. The girl envies the new frock of 13-year-old Sara (she "turned quite red" at the sight of Sara in new clothes) and treats her "scathingly" (Burnett 1995: 221). It seems rather strange for the grown-up young lady to envy the clothes of a younger teenager and to consider a much younger girl, especially one in such distress, as a rival.

The reason for these tricks with time may be the whole atmosphere of the school. Miss Minchin does not really care about the upbringing of her pupils; she does not even try to understand them. One of the examples is Sara's friend Ermengarde. At the very beginning of the novel, she is described as a child who is unhappy because of her reputation of being an "unmistakably dull creature" (according to her "clever father") who "must be made to learn" (emphasis by V.A., Burnett 1995: 28-29). At first, listening to Sara's perfectly fluent French, she looks "a little frightened" (27), startled by the new pupil's abilities. But later on, Sara surprises the new acquaintance with a compliment 
("It [the name Ermengarde] sounds like a story book", (29) and the girls become best friends. After the change in Sara's life, the friendship does not come to an end, which is good for both girls. Sara gladly goes to the attic knowing that Ermengarde will be there ("The mere presence of plump, comfortable Ermengarde [...] would warm it a little", 180). As for Ermengarde, she also finds comfort in Sara's cleverness, love of books ('I'll read them - and tell you everything that's in them afterwards [...]. The little ones always remember what I tell them", 182), Sara's imagination (eager to help a hungry friend she brings Sara and Becky a basket with tasty presents from her aunt for the "pretend party": "Pretend you are a princess now and this is a royal feast", 197) and the ability to give emotional support ("Perhaps to be able to learn things quickly is not everything. [...] Lots of clever people have done harm and have been wicked", 183). Thus, Ermengarde receives the support that she needs from the other pupil rather than from the teachers or Miss Minchin. The grown-ups do not even think of helping Ermengarde with her studies. Miss Minchin certainly does not, and Ermengarde is only scolded and reprimanded ("Miss St. John!" she exclaimed severely. "[...]Remove your elbows! [...] Sit up at once!", 28). And the "pretend party" ends up with both Ermengarde and Sara being punished (Burnett 1995: 200):

"I will attend to you tomorrow. You shall have neither breakfast, dinner, nor supper!" [...]

"And you" - to Ermengarde - "have brought your beautiful new books into this dirty attic. Take them up and go back to bed. You will stay there all day tomorrow, and I shall write to your papa. [...]."

It seems Miss Minchin does not understand such simple things as friendship, to say nothing of what we call nowadays an individual approach (a concept unknown in the $19^{\text {th }}$ century as a term but at all times understood by those who really loved children and cared for them). The pupils at Miss Minchin's have the opportunity to develop only if they understand, as Sara did, that their maturity is their own responsibility.

By the end of both novels the problem of living without a parent is solved. While David has to take his own future in his hands to go and find Miss Trotwood, Sara's story is somewhat different. Perhaps this is because even at the beginning of the novel the girl is already perfectly capable of taking care of herself and answering for herself. Her whole ordeal, except for her father's death, appears to be a misunderstanding, an unfortunate combination of circumstances. Her father's partner and his friends have been looking for her all the time since Captain Crewe's death; she can be happy again when she is found. But she also wins the right to be happy by keeping her moral principles, being a Princess even in rags: "I tried not to be anything else [...] even when I was coldest and hungriest [...]" (Burnett 1995: 243). It is interesting that precisely on the morning after the interrupted forbidden party Sara gets the first present via Carrisford's servant Ram Dass. Later, he will introduce Sara to his monkey. The runaway animal will lead Sara to her new guardian's door. Like David, Sara also finds a lonely man who not only can take care of her, but also needs her presence as a "Missee sahib", a little lady of the house to be his comfort and companion. Unlike the orphans of other pieces of fiction of the $19^{\text {th }}$ and 
the beginning of the $20^{\text {th }}$ centuries, neither Sara nor David can, as Melanie A. Kimball put it, "transform the lives around them [like Mary Lennox does in the other book by F.H. Burnett, The Secret Garden]" (Kimball 1999: 567), but like orphans in many folklore stories they "overcome obstacles by their virtuous behavior" (561) and have the ability to take full responsibility for their own life, future, and upbringing.

In the Russian screen version of A Little Princess (1997, directed by V. Grammatikov) there is another idea of bringing the two parts of Sara's life together, partly based on the unhappy birthday concept. At the end of the film, there is a scene where Sara gives a party in her new home. All the inhabitants of Miss Minchin's Academy, including the schoolmistress's sister Miss Amelia and Miss Minchin's pet dog, take part, but not Miss Minchin herself. Although it is a Christmas party, not a birthday party, the cycle is complete: the interrupted holiday is resumed; Sara Crewe is again a child who can grow, learn and be happy on her birthday. So, the circumstances of Sara's and David's unhappy birthdays and the death of their parents are very different. Sara's life is ruined by the death of her father, while David's ordeal began long before his mother's death. However, David can mourn his mother properly, while Sara cannot. In searching for a new home and a new guardian, David is more active than Sara, but the changes in him caused by his mother's death are deeper: he comes to maturity through the tragedy. Sara, on the other hand, is already a very clever, mature child and she changes very little with her father's death. Her task is to fight for her principles and keep to them to gain the right to happiness in the future. What is common in both novels is the news of the death of a parent on the child's birthday, which forms the beginning of the initiation process. Both children also learn much about the cruelty and hostility of the world and they have to defend themselves. They understand fully that their life, who they are, and their future are their own responsibility now. Both David and Sara become somewhat isolated from the world, but they break the circle of isolation to find a substitute for their dead parents. Under the care of loving guardians, they can continue on their way to adulthood and happiness.

\section{References}

Andrews, Malcolm. 2000. Childhood. In Oxford Reader's Companion to Dickens, ed. by Paul Schlicke, 90-94. Oxford: Oxford University Press.

Burnett, Frances Hodgson. 1995. A Little Princess. London: Penguin Books.

Byachkova, Varvara Andreevna [Бячкова, Варвара Андреевна]. 2015. «Граница детства» в викторианском романе [The "Boundaries of Childhood" in the Victorian Novel]. Мировая литература в контексте культуры [World Literature in the Context of Culture] 10 (4): 25-32.

Carey, John. 1991. The Violent Effigy. A Study of Dickens' Imagination. London, Boston: Faber and Faber.

Carpenter, Humphrey. 1985. Secret Gardens: A Study of the Golden Age of Children's Literature. London, Sydney: Unwin Paperbacks.

Cory, Charlotte. 2013. Emma Brown by Clare Boylan. [Book Review]. Independent (14 October 2013). <https://www.independent.co.uk/arts-entertainment/books/reviews/ emma-brown-by-clare-boylan-86630.html> (accessed 10 June 2018). 
Coveney, Peter. 1967. The Image of Childhood. London: Penguin Books.

Dickens, Charles. 2000. David Copperfield. London: Wordsworth Classics.

Fielding, K.J. 1960. Charles Dickens. London: Longmans.

Flanders, Judith. 2004. The Victorian House. London: Harper Perennial.

Grylls, David. 1978. Guardians and Angels. Parents and Children in Nineteenth-Century Literature. London, Boston: Faber and Faber.

Kimball, Melanie A. 1999. Orphan Characters in Children's Fiction. Library Trends 47 (3): 558-578.

Propp, Vladimir Yakovlevich [Пропп, Владимир Яковлевич]. 2000. Исторические корни волшебной сказки [The Historical Roots of the Fairy Tale]. Москва: Лабиринт.

Shakespeare, William. 2005. The Complete Works. Oxford: Oxford University Press.

Wynne, Deborah. 2015. Reading Victorian Rags: Recycling, Redemption, and Dickens's Ragged Children. Journal of Victorian Culture 20 (1): 34-49. DOI: 10.1080/13555502.2014.991747.

\section{Varvara A. Byachkova}

Državno sveučilište u Permu, Rusija

\section{Nesretni rođendani u romanima F. H. Burnett (Mala princeza) i Charlesa Dickensa (David Copperfield)}

Ovaj rad posvećen je „nesretnim rođendanima“ u romanima Charlesa Dickensa i Frances Hodgson Burnett. Ti autori slijede folklornu tradiciju u prikazivanju mladih likova koji se nakon smrti i drugoga roditelja moraju sami brinuti za sebe. U romanima David Copperfield i Mala princeza (A Little Princess), novost o smrti stiže na djetetov rođendan. Članak razmatra zbog čega se odabire upravo taj dan, pod kojim okolnostima djeca preživljavaju svoju traumu i što ih čini sposobnima za daljnji život. Vijest o smrti roditelja na dječji rođendan obilježava, čini se, novo razdoblje u životima protagonista navedenih romana $\mathrm{i}$ predstavlja svojevrsni životni ispit koji se mora proći. Jednom kad svlada tu poteškoću i postigne moralnu pobjedu nad okolnostima, dijete dobiva priliku za daljnji život i, ponovno, za sreću.

Ključne riječi: rođendan, djeca, F. H. Burnett, Charles Dickens, viktorijanski roman, edvardijanski roman 